\title{
Ruminal parameters and nitrogen balance in sheep fed diets containing residue from the extraction of tamarind pulp
}

\section{Parâmetros ruminais e balanço de nitrogênio em ovinos alimentados com rações contendo resíduo da extração da polpa de tamarindo}

\author{
Luiz Juliano Valério Geron ${ }^{1 *}$; Jocilaine Garcia ${ }^{1}$; Fabiana Gomes da Costa ${ }^{2}$; \\ Sílvia Cristina de Aguiarr'; Edimar Barbosa de Oliveira²; Maria Isabel Leite da Silva²; \\ Luciano da Silva $\mathrm{Cabral}^{3}$; Maria Aparecida Pereira Pierangeli ${ }^{1}$; Lúcia Maria Zeoula \\ Alexandre Agostinho Mexia ${ }^{1}$
}

\begin{abstract}
This study measured the ruminal parameters, feed intake, fecal and urinary $\mathrm{N}$ production, and $\mathrm{N}$ balance (NB) in sheep fed increasing levels of residue from the extraction of tamarind pulp (RETP) on a $0.0 \%$, $5.0 \%, 10.0 \%$, and $15.0 \%$ dry matter (DM) basis. Four mixed-breed male sheep weighing $40.38 \pm 2.10 \mathrm{~kg}$ of body weight were distributed in a $4 \times 4$ Latin square design. The animals were allocated to metabolism cages and fed twice a day. Each experimental period lasted 20 days. The $\mathrm{pH}$ and concentration of ammonia nitrogen $\left(\mathrm{NH}_{3}-\mathrm{N}\right)$ in ruminal fluid were measured. Nitrogen intake (NI), fecal $\mathrm{N}(\mathrm{FN})$, urinary $\mathrm{N}(\mathrm{UN})$, absorbed $\mathrm{N}(\mathrm{AN})$, and NB were expressed in $\mathrm{g} \cdot \mathrm{day}^{-1}$, percentage of consumed nitrogen $(\mathrm{CN})$, and $\mathrm{g} \cdot \mathrm{kg}^{-1}$ of metabolic weight $\left(\mathrm{g} \cdot\left(\mathrm{kg}^{0.75}\right)^{-1}\right.$. Statistical analysis of these variables was performed by evaluating the variance and regression at $5 \%$ probability. The levels of RETP did not alter ( $>0.05)$ the $\mathrm{pH}$ level or $\mathrm{NH}_{3}-\mathrm{N}$ concentration in the rumen fluid, but a quadratic behavior for the same values after feeding $(p<0.05)$ was observed. The inclusion of RETP in the diet did not change ( $p>0.05)$ NI, UN, the $\mathrm{AN}$ in $\mathrm{g} \cdot \mathrm{day}^{-1}$ and $\mathrm{g} \cdot\left(\mathrm{kg}^{0.75}\right)^{-1}, \mathrm{NB}$ in $\mathrm{g} \cdot \mathrm{day}^{-1}$ and $\mathrm{g} \cdot\left(\mathrm{kg}^{0.75}\right)^{-1}$, or the percentage of $\mathrm{CN}$. However, the AN as a percentage of $\mathrm{CN}$ showed a linear effect $(\mathrm{p}<0.05)$ with the inclusion of RETP in experimental diets. For FN in $\mathrm{g} \cdot$ day $^{-1}$ and $\mathrm{g} \cdot\left(\mathrm{kg}^{0.75}\right)^{-1}$, no difference was observed $(\mathrm{p}>0.05)$ with the inclusion of RETP, but for FN expressed as a percentage of $\mathrm{CN}$, a linear increase $(\mathrm{p}<0.05)$ was observed with the inclusion of RETP. Thus, we concluded that diets with up to $15.0 \%$ RETP do not alter the $\mathrm{pH}$ and $\mathrm{NH}_{3}-\mathrm{N}$ in ruminal fluid, NI, UN, or NB. In addition, the inclusion of $15.0 \%$ RETP has a laxative affect.

Key words: Ammonia nitrogen, absorbed nitrogen, ruminal $\mathrm{pH}$, urine, nitrogen balance
\end{abstract}

\section{Resumo}

Avaliou-se os parâmetros ruminais, o consumo, a produção fecal e urinária de nitrogênio e o balanço de nitrogênio (BN) em ovinos alimentados com níveis crescentes de resíduo da extração da polpa de tamarindo - REPT $(0,0 \%, 5,0 \%, 10,0 \%$ e $15,0 \%$ na MS). Foram utilizados quatro ovinos sem padrão racial definido (SPRD), não castrados, com peso corporal (PC) médio de 40,38 $\mathrm{kg} \pm 2,10 \mathrm{~kg}$ alocados

\footnotetext{
${ }^{1}$ Profs., Universidade do Estado de Mato Grosso, UNEMAT, Pontes e Lacerda, MT, Brasil. E-mail: 1jgeron@yahoo.com.br; jo@ unemat.br; scaguiar@unemat.br; mappierangeli@gmail.com; alexandre@unemat.br

2 Discentes do Curso de Mestrado, Pós Graduação em Ciências Animal, Universidade Federal de Mato Grosso, UFMT, Cuiabá, MT, Brasil.E-mail: fabiana_gcosta@hotmail.com; edimarzoo@hotmail.com; mariaisabelmt@hotmail.com

3 Prof., UFMT, Cuiabá, MT, Brasil. E-mail: lucianoufmt@gmail.com

${ }^{4}$ Prof ${ }^{a}$, Universidade Estadual de Maringá, UEM, Maringá, PR, Brasil. E-mail: lmzeoula@uem.br

* Author for correspondence
} 
em gaiolas de metabolismo, alimentados duas vezes ao dia. Foi utilizado um delineamento experimental em quadrado latino 4X4. Cada período experimental teve duração de 20 dias. Os parâmetros ruminais mensurados foram o $\mathrm{pH}$ e a concentração do nitrogênio amoniacal $\left(\mathrm{N}-\mathrm{NH}_{3}\right)$ do líquido ruminal. Os dados de consumo de nitrogênio $(\mathrm{N}), \mathrm{N}$ fecal, $\mathrm{N}$ urinário, $\mathrm{N}$ absorvido e $\mathrm{BN}$ expressos em $\mathrm{g} \mathrm{dia}^{-1} ; \%$ do nitrogênio consumido (NC) e gramas por quilograma de peso metabólico $\left(\mathrm{g} \mathrm{kg}^{0,75-1}\right)$ foram submetidos á análise de variância (ANOVA) e testados utilizando equação de regressão a 5\% de probabilidade. Foi observado que os níveis de REPT não alteraram $(\mathrm{p}>0,05)$ o comportamento do $\mathrm{pH}$ e a concentração do $\mathrm{N}_{-} \mathrm{NH}_{3}$ do líquido ruminal, porém foi observado que o tempo após alimentação alterou de forma quadrática $(\mathrm{p}<0,05)$ o valor de $\mathrm{pH}$ e a concentração do $\mathrm{N}^{-\mathrm{NH}_{3}}$ do líquido ruminal dos ovinos. Foi observado que a inclusão do REPT na alimentação de ovinos não alterou ( $\mathrm{p}>0,05)$ o consumo de $\mathrm{N}$, $\mathrm{N}$ urinário e $\mathrm{N}$ absorvido em $\mathrm{g} \mathrm{dia}^{-1}, \mathrm{~g} \mathrm{~kg}^{0,75-1} \mathrm{e}$ o balanço de nitrogênio (BN) $\mathrm{g} \mathrm{dia}^{-1}, \mathrm{~g} \mathrm{~kg}^{0,75-1} \mathrm{e}^{\%}$ do nitrogênio consumido (NC). Porém o $\mathrm{N}$ absorvido em $\%$ do NC apresentou um efeito linear decrescente $(\mathrm{p}<0,05)$ com a inclusão do REPT nas rações experimentais. Para o nitrogênio fecal em $\mathrm{g} \mathrm{dia}^{-1}, \mathrm{~g} \mathrm{~kg}^{0,75-1}$ não foi observado diferença ( $\mathrm{p}>0,05)$ com a inclusão do REPT, porém para o $\mathrm{N}$ fecal expresso em \% NC dos ovinos foi alterado $(\mathrm{p}<0,05)$ de maneira linear crescente com a inclusão do REPT nas rações. Assim, conclui-se que a inclusão de até $15,0 \%$ de resíduo da extração da polpa de tamarindo na alimentação de ovinos não altera o valor de $\mathrm{pH}$ e nitrogênio amoniacal do líquido ruminal, o consumo de nitrogênio, nitrogênio urinário e balanço de nitrogênio. A inclusão de $15,0 \%$ de resíduo da extração da polpa de tamarindo atua como agente laxativo.

Palavras-chave: Nitrogênio amoniacal, nitrogênio absorvido, $\mathrm{pH}$ do líquido ruminal, urina

\section{Introduction}

With the growing industrialization of Brazil, the production of residue and co-products from agro-industry is increasing. Some of these residues are unusable and considered pollutants. Most, however, can be used in ruminant feed, which reduces production costs and transforms residue materials of low nutritional content into market products with high value, such as meat and milk. The use of agro-industry residues as alternative foods facilitates livestock production and reduces the problems caused by the disposal of residues in the environment (GERON et al., 2011).

The fruit of the tamarind tree (Tamarindus indica L.) is distinguished by its excellent nutritional value, pleasant aroma, and sweet-sour taste. In addition, tamarind is widely used in the manufacture of soft drinks, ice creams, pastes, jams, and liqueurs, and is commonly used as an ingredient in condiments and sauces, particularly in the familiar agriculture of the Central-West and Northeast regions of Brazil (PEREIRA et al., 2004).

It is hypothesized that use of the residue from the extraction of tamarind pulp (RETP) in ruminant feed may change the dynamics of rumen fermentation because the protein in the pulp can be converted to ammonia $\left(\mathrm{NH}_{3}\right)$ by various proteolytic microorganisms present in the rumen. Although some species of bacteria can incorporate amino acids and peptides directly into microbial protein, approximately $40 \%$ to $70 \%$ of bacterial $\mathrm{N}$ passes through the ruminal $\mathrm{NH}_{3}$ pool (HRISTOV; BRODERICK, 1994).

Several factors, including the proportion of roughage to concentrate in the diet, the frequency of feeding, and protein and carbohydrate sources in the diet, can alter rumen fermentation, the concentration of short-chain fatty acids and $\mathrm{NH}_{3}-\mathrm{N}$ in the rumen fluid, the fluctuation of ruminal $\mathrm{pH}$, and fiber digestion (ZEOULA et al., 2006; MAEDA et al., 2007).

Roughage is an important component in the diet of feedlot ruminants because fiber stimulates mastication and rumination (VAN SOEST, 1994). A study on sheep conducted by Geron et al. (2015) showed that rations with inappropriate levels of concentrate that do not adequately stimulate rumination can reduce saliva production, resulting 
in both a decreased ruminal $\mathrm{pH}$ and digestibility of fiber.

According to Zeoula et al. (2014), many factors affect the degradation of crude protein (CP) in the rumen, including the chemical composition of and physical $\mathrm{CP}$, microbial proteolytic activity, the access of bacteria to the protein, food retention time in the rumen, ruminal $\mathrm{pH}$, food processing, room temperature, and the use of additives to modify ruminal fermentation.

Nitrogen balance (NB) is an important value that denotes $\mathrm{N}$ utilization by ruminants and its loss to the environment (HENRIQUE et al., 2003). Nitrogen balance is calculated by subtracting the amount of $\mathrm{N}$ excreted via feces and urine from the amount of $\mathrm{N}$ ingested. Further, NB is a marker of protein metabolism, which is used to evaluate the diet and determine if an animal's nitrogenous compounds are in equilibrium (GUIMARÃES JÚNIOR et al., 2007; GERON et al., 2013a).

Nitrogen balance may reflect how animals metabolize end-products and their $\mathrm{N}$ excretion, and is positively correlated with the concentration of urea found in urine, which is determined by the $\mathrm{N}$ concentration in plasma and intake of $\mathrm{N}$ by the animals (VAN SOEST, 1994).

The objective of our study was to evaluate the effect of RETP in the diet of sheep on ruminal parameters, feed intake, fecal and urinary $\mathrm{N}$ production, and NB.

\section{Material and Methods}

The study was conducted at the Universidade do Estado de Mato Grosso (UNEMAT) in the University Campus de Pontes e Lacerda, at the Animal Metabolism Sector and Food and Animal Nutrition Analysis Laboratory, located $15^{\circ} 15^{\prime} 05^{\prime \prime} \mathrm{S}$ latitude and $59^{\circ} 13^{\prime} 26^{\prime \prime} \mathrm{W}$ longitude and an altitude of $295 \mathrm{~m}$.
Four mixed-breed male sheep, each with a body weight of $40.38 \pm 2.10 \mathrm{~kg}$, were used in the experiment. The sheep were allocated to metabolism cages containing individual feeders and waterers. The experiment rations were provided twice a day. The sheep were dewormed with an ivermectinbased product 15 days before the trial began.

Ten grams of a mineral mixture was added directly to the concentrate of each animal's meal twice a day $\left(5 \mathrm{~g}\right.$ salt $\cdot$ animal $^{-1} \cdot$ meal $\left.^{-1}\right)$. The chemical composition of the mineral supplement was as follows: $120 \mathrm{~g} \mathrm{Ca} \cdot \mathrm{kg}^{-1} ; 85 \mathrm{~g} \mathrm{P} \cdot \mathrm{kg}^{-1} ; 16 \mathrm{~g} \mathrm{~S} \cdot \mathrm{kg}^{-1} ; 148$ $\mathrm{g} \mathrm{Na} \cdot \mathrm{kg}^{-1} ; 50 \mathrm{mg} \mathrm{Co} \cdot \mathrm{kg}^{-1} ; 500 \mathrm{mg} \mathrm{Cu} \cdot \mathrm{kg}^{-1} ; 16 \mathrm{mg}$ $\mathrm{Se} \cdot \mathrm{kg}^{-1}$; and $4800 \mathrm{mg} \mathrm{Zn} \cdot \mathrm{kg}^{-1}$.

We used a $4 \times 4$ Latin square experimental design, with four animals, four periods, and four experimental rations with increasing levels of $\operatorname{RETP}(0.0 \%, 5.0 \%, 10.0 \%$, and $15.0 \%)$. According to Gurjão (2006), tamarind and its by-products may have phenolic substances that can act as a laxative in animals, and so the rations did not exceed $15 \%$ RETP.

The RETP was obtained from an existing industry located in Pontes e Lacerda - MT. The residue consisted of the fruit peel, seed, and pulp, which was adhered to the seed after extraction of the fruit. The RETP was dried in the sun for $72 \mathrm{~h}$.

The experimental diets (Table 1) contained corn silage and concentrate that consisted of ground corn, cassava flour, soybean meal, urea, and RETP (Tamarindus indica L.) in increasing amounts.

The experimental diets were formulated to contain $0.0 \%, 5.0 \%, 10.0 \%$, and $15.0 \%$ RETP. The proportion of roughage used in the experimental diets was $50 \%$ corn silage and $50 \%$ concentrate. The rations were balanced with an average of $15 \%$ CP (isoproteic) and 69\% total digestible nutrients (isocaloric) according to the National Research Council (NRC, 2007) for a moderate gain of approximately $0.150 \mathrm{~kg} \cdot \mathrm{day}^{-1}$, as shown in Table 2 . 
Table 1. Chemical composition of experimental foods.

\begin{tabular}{lcccccc}
\hline \multirow{2}{*}{\multicolumn{1}{c}{ Variables }} & \multicolumn{7}{c}{ Experimental food } \\
\cline { 2 - 6 } & COS $^{1}$ & CGG $^{2}$ & CAF $^{3}$ & SOM $^{4}$ & RETP $^{5}$ & Ureia $^{6}$ \\
\hline Dry matter \% & 25.12 & 91.68 & 90.74 & 90.35 & 83.49 & 97.68 \\
Organic matter \% & 92.16 & 97.22 & 94.97 & 93.37 & 96.28 & $-{ }^{6}$ \\
Crude protein \% & 8.25 & 9.83 & 2.95 & 47.55 & 8.52 & 282.6 \\
Ether extract \% & 1.61 & 4.34 & 0.30 & 1.51 & 1.09 & - \\
Neutral detergent fiber \% & 68.58 & 13.63 & 10.30 & 17.80 & 50.62 & - \\
Acid detergent fiber \% & 41.03 & 11.31 & 4.13 & 16.66 & 38.02 & - \\
Crude fiber \% & 32.30 & 9.05 & 3.30 & 13.33 & 30.42 & - \\
No-nitrogen extract \% & 52.52 & 74.00 & 88.42 & 31.23 & 57.47 & - \\
Total carbohydrates \% & 82.30 & 83.05 & 91.72 & 44.31 & 86.67 & - \\
No-fibrous carbohydrate \% & 13.72 & 69.42 & 81.42 & 26.51 & 36.04 & - \\
Mineral matter \% & 4.79 & 2.78 & 5.03 & 6.38 & 2.50 & - \\
Total digestible nutrients \% & 62.30 & 86.03 & 74.00 & 80.73 & 54.40 & - \\
\hline
\end{tabular}

${ }^{1}$ corn silage, ${ }^{2}$ corn ground grain, ${ }^{3}$ cassava flour, ${ }^{4}$ soybean meal, ${ }^{5}$ residue from the extraction of tamarind pulp, ${ }^{6}$ trace nutrient in the experimental food. Total carbohydrates $(\mathrm{TC})=\mathrm{OM}-[\mathrm{EE}+\mathrm{CP}]$ and not fibrous carbohydrate $(\mathrm{NFC})=100-(\mathrm{CP}+\mathrm{NDF}+\mathrm{EE}$ + MM) second Sniffen et al. (1992).

Table 2. Percentage and chemical composition of the experimental rations containing different levels of inclusion of residue from the extraction of tamarind pulp (RETP) provided to sheep.

\begin{tabular}{|c|c|c|c|c|}
\hline \multirow[t]{2}{*}{ Foods } & \multicolumn{4}{|c|}{$\begin{array}{l}\text { Inclusion levels of residue from the extraction of tamarind pulp in } \\
\text { the experimental rations }\end{array}$} \\
\hline & $0 \%$ & $5 \%$ & $10 \%$ & $15 \%$ \\
\hline Corn silage & 50.00 & 50.00 & 50.00 & 50.00 \\
\hline Corn ground grain & 15.40 & 16.00 & 23.00 & 23.00 \\
\hline Cassava flour & 19.00 & 14.00 & 4.00 & 0.00 \\
\hline Soybean meal & 15.00 & 14.40 & 12.40 & 11.40 \\
\hline Residue from the extraction of tamarind pulp & 0.00 & 5.00 & 10.00 & 15.00 \\
\hline Ureia & 0.60 & 0.60 & 0.60 & 0.60 \\
\hline \multicolumn{5}{|l|}{ Chemical composition } \\
\hline Dry matter & 58.06 & 57.70 & 57.41 & 57.06 \\
\hline Organic matter & 93.10 & 93.19 & 93.45 & 93.53 \\
\hline Crude protein & 15.03 & 15.08 & 1495 & 14.80 \\
\hline Ether extract & 1.76 & 1.81 & 2.11 & 2.14 \\
\hline Neutral detergent fiber & 41.02 & 43.01 & 45.11 & 47.05 \\
\hline Acid detergent fiber & 25.54 & 27.20 & 29.15 & 30.72 \\
\hline Crude fiber & 20.43 & 21.76 & 23.32 & 24.58 \\
\hline No-nitrogen extract & 59.14 & 57.85 & 56.44 & 55.46 \\
\hline Total carbohydrates & 78.01 & 79.99 & 78.08 & 78.30 \\
\hline No-fibrous carbohydrate & 37.00 & 34.98 & 32.97 & 31.25 \\
\hline Mineral matter & 4.74 & 4.59 & 4.28 & 4.14 \\
\hline Total digestible nutrients & 70.57 & 69.92 & 69.35 & 68.30 \\
\hline
\end{tabular}

TDN estimated from the values of the chemical composition of food. 
The ration was weighed each day and the animals had free access to the food, and so refusals represented only $10 \%$ of the total feedings. The animals were fed at 6:00 a.m. and 6:00 p.m.

Samples of corn silage were collected from different sites in the silo to determine the DM content. During the experimental period, feed leftover samples were collected for each animal, period, and treatment.

For the measurement of total feces, a collection bag was attached to each sheep during the experimental period. Each animal's feces were weighed every morning and homogenized and composite samples representing $10 \%$ of the total weight were taken (GERON et al., 2013a). The samples were then placed in plastic bags that were identified with the animal and experimental period and stored in a freezer at $-10^{\circ} \mathrm{C}$ for further analysis.

On the last day of each collection period, samples of ruminal fluid were collected. The samples were taken before the first feeding $(6 \mathrm{~h})$, which was established as time zero (0), and then at 2, 4, 6, and $8 \mathrm{~h}$ post feeding, with five samples per animal per period. For the collection, a vacuum pump (40 mm $\mathrm{Hg}$ pressure) attached to a silicone hose $(2.0 \mathrm{~m}$ long $\times 12.0 \mathrm{~mm}$ diameter) lubricated with mineral oil (Nujol) was introduced into the mouth of the animal (ZEOULA et al., 2003).

For $\mathrm{NH}_{3}-\mathrm{N}$ determination, the sample was filtered to obtain $100 \mathrm{~mL}$ of ruminal fluid. Immediately after collection, the $\mathrm{pH}$ of the sample was measured from $50 \mathrm{~mL}$ of the ruminal fluid using a digital $\mathrm{pH}$ meter. One milliliter of sulfuric acid $\left(\mathrm{H}_{2} \mathrm{SO}_{4} 1: 1\right)$ was then added to stop fermentation. The $\mathrm{NH}_{3}-\mathrm{N}$ level was determined by distillation with potassium hydroxide $2 \mathrm{~N}$, using the method described by Fenner (1965), and later modified by Vieira (1980).

For the collection of total urine, plastic buckets covered with screens to prevent contamination with hair, feed, and feces, were placed below the metabolism cages. Twenty milliliters of hydrochloric acid (HCl 1:1) was added to each bucket to prevent bacterial degradation of purine derivatives and uric acid precipitation. Urine was collected at the same time each morning. Urine samples $(10 \%$ of total production) were stored in the refrigerator $\left(5^{\circ} \mathrm{C}\right)$ for further analysis (ZEOULA et al., 2006).

After the experimental period concluded, feed and feces samples were dried in a ventilated oven $\left(55^{\circ} \mathrm{C}\right.$ for $\left.72 \mathrm{~h}\right)$, ground to $1 \mathrm{~mm}$ diameter, and then mixed in equal quantities based on dry weight to form composite samples. The $\mathrm{N}$ content of feed, urine, and feces was calculated using the semimicro Kjeldahl method, using 6.25 as the conversion factor for CP, as described by Silva and Queiroz (2002). Mineral matter (MM) was determined by incineration in a muffle furnace at $600^{\circ} \mathrm{C}$ and then obtaining the value of organic matter (OM) by difference, and the ether extract (EE) content was determined by extraction washing with petroleum ether, as described by Silva and Queiroz (2002). The concentrations of neutral detergent fiber (NDF) and acid detergent fiber (ADF) were determined by the method of Van Soest et al. (1991).

The NB, or retained nitrogen, was obtained using the following formula: $\mathrm{NB}=[(\mathrm{N}$ supplied $\mathrm{g}$ - N scraps $\mathrm{g}$ ) - ( $\mathrm{N}$ feces $\mathrm{g}+\mathrm{N}$ urine $\mathrm{g})$ ] as described by Zeoula et al. (2006). The absorbed nitrogen (AN) was calculated using the following equation: $\mathrm{AN}=$ [( $\mathrm{N}$ provided $\mathrm{g}-\mathrm{N}$ scraps $\mathrm{g})-(\mathrm{N}$ feces $\mathrm{g})]$, and $\mathrm{N}$ intake $(\mathrm{NI})$ by the equation: $\mathrm{NI}=[(\mathrm{N}$ provided $\mathrm{g}-\mathrm{N}$ scraps g)], as written by Moreno et al. (2010).

Data variance and regression were analyzed using the Statistics and Genetic Analysis System program - SAEG (UFV, 2007). Treatment mean differences were determined by the Tukey test. Tests that had a $p \leq 0.05$ were considered statistically significant. Statistical analyses of ruminal parameters $(\mathrm{pH}$ and $\mathrm{NH}_{3}-\mathrm{N}$ ) were performed in a split-plot design, with treatments in the plots and collection times as subplots. 


\section{Results and Discussion}

The different levels of RETP $(0.0 \%, 5.0 \%$, $10.0 \%$, and $15.0 \%$ ) in the diets did not affect $(\mathrm{p}>0.05)$ the $\mathrm{pH}$ of rumen liquid, which had an average $\mathrm{pH}$ of 6.67 . However, the $\mathrm{pH}$ of ruminal fluid differed significantly $(\mathrm{p}<0.05)$ relative to the time elapsed since feeding, with the $\mathrm{pH}$ demonstrating a quadratic behavior dependent on the level of inclusion of RETP (Figure 1), where $\mathrm{pH}=6.9302-0.206455 \mathrm{X}+0.0233929 \mathrm{X}^{2}$ and $\mathrm{r}^{2}=$ $23.18 \%$.

Figure 1. Value of the $\mathrm{pH}$ of the rumen fluid of sheep fed different levels of residue from the extraction of tamarind pulp in relation to time (hours) after the first meal of the day.

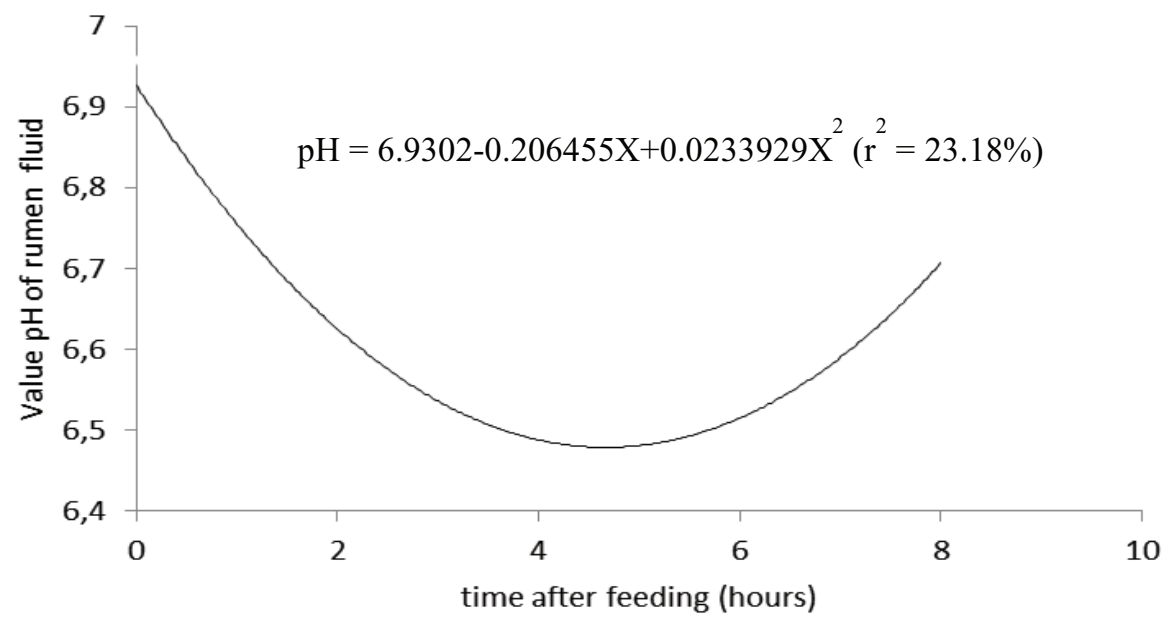

The minimum average value of the ruminal $\mathrm{pH}$ was 6.47 at $4 \mathrm{~h} 24 \mathrm{~min}$ after feeding, with the $\mathrm{pH}$ ranging from 6.48 at $4 \mathrm{~h} 00 \mathrm{~min}$ after feeding to 6.96 at $0 \mathrm{~h} 00 \mathrm{~min}$ before the morning feeding. This decrease in ruminal fluid $\mathrm{pH}$ after feeding was correlated with an increased production of short-chain fatty acids from the fermentation of dietary carbohydrates in the rumen (ZEOULA et al., 2006). The return of the $\mathrm{pH}$ to near neutrality after $4 \mathrm{~h} 24 \mathrm{~min}$ was probably due to the buffering mechanisms of the rumen, including salivary activity, fiber rumination, and acid absorption by the rumen epithelium. A rising $\mathrm{pH}$ of 6.75 was observed at $2 \mathrm{~h} 00 \mathrm{~min}$ after the morning feeding in diets with average values of $44.05 \% \mathrm{NDF}$ and $34.05 \%$ no-fiber carbohydrate (NFC), which is consistent with Van Soest's (1994) findings that diets must contain sufficient amounts of fiber to stimulate salivation and the buffering effects of rumination (Figure 1).
The inclusion of $0.0 \%, 5.0 \%, 10.0 \%$, and $15.0 \%$ RETP in the diets did not change $(p>0.05)$ the concentration of $\mathrm{NH}_{3}-\mathrm{N}$ of rumen fluid, which had an average value of $19.01 \mathrm{mg} \cdot 100 \mathrm{~mL}^{-1}$ (Figure 2), a value above the ideal level of $15.00 \mathrm{mg} \cdot 100 \mathrm{~mL}^{-1}$ needed for maximum ruminal fermentation activity, and greater than the concentration of $5.00 \mathrm{mg} \cdot 100$ $\mathrm{mL}^{-1}$, which can limit microbial growth (PEREIRA et al., 2009).

However, the $\mathrm{NH}_{3}-\mathrm{N}$ concentration in rumen fluid after the morning feeding exhibited a quadratic behavior $(\mathrm{p}<0.05)$ for all inclusion levels, where $\mathrm{NH}_{3}-\mathrm{N}=19.0644+1.04094 \mathrm{X}-0.17578 \mathrm{X}^{2}$ and $\mathrm{r}^{2}$ $=20.87 \%$ (Figure 2 ). The maximum mean value of $\mathrm{NH}_{3}-\mathrm{N}$ in the rumen fluid was $20.61 \mathrm{mg} \cdot 100 \mathrm{~mL}^{-1}$ obtained at $3 \mathrm{~h} 00 \mathrm{~min}$ after the morning feeding.

The inclusion of RETP did not change $(p>0.05)$ the intake of $\mathrm{N}$ and fecal excretion of $\mathrm{N}$, calculated in $\mathrm{g} \cdot \mathrm{day}^{-1}$ and $\mathrm{g} \cdot\left(\mathrm{kg}^{0.75}\right)^{-1}$ (Table 3). However, NI 
$\left(\mathrm{g} \cdot \mathrm{day}^{-1}\right)$ increased by $7.36 \%$ and $6.32 \%$ for the diets containing $10.0 \%$ and $15.0 \%$ RETP, respectively, compared to the rations with no RETP. This may be due to the RETP increasing FN excretion by $16.05 \%$ (in the diet with $10.0 \%$ RETP) and $25.69 \%$ (in the diet with $15 \%$ RETP), compared to the diet without RETP. Thus, the sheep took in more $\mathrm{N}$ either because it was not absorbed by the digestive tract, or because of the laxative effect of tamarind (GURJÃO, 2006). According to Geron et al. (2013b), the inclusion of $0.0 \%, 5.0 \%, 10.0 \%$, and $15.0 \%$ RETP did not change $(\mathrm{p}>0.05)$ CP intake in $\mathrm{g} \cdot \mathrm{day}^{-1}$; however, a variation of $5.71 \%$ was observed in the intake of $C P$ in rations containing RETP compared to the diets without RETP.

Figure 2. The concentration of ammoniacal nitrogen $\left(\mathrm{NH}_{3}-\mathrm{N}\right)$ of sheep's rumen fluid fed to the different levels of residue from the extraction of tamarind pulp in relation of time (hours) after the first meal of the day.

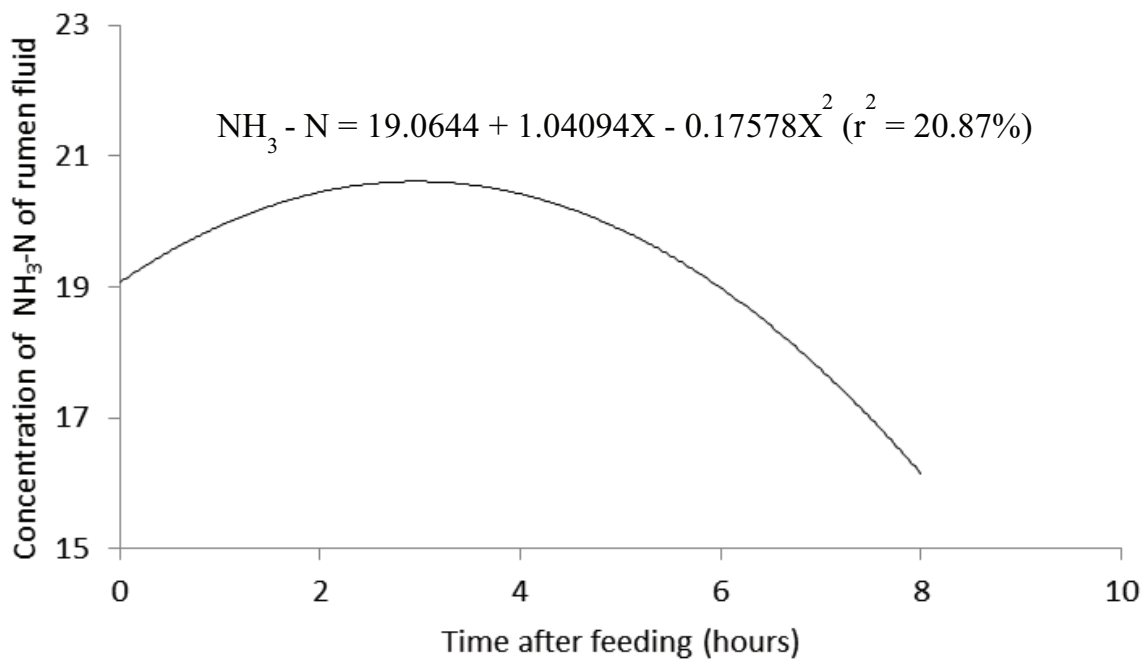

Table 3. Values intake, fecal and urinary excretion of nitrogen, nitrogen balance, absorbed nitrogen (g day $\left.{ }^{-1}\right)$ and nitrogen balance compared with nitrogen absorbed to sheep fed with different levels residue from the extraction of tamarind pulp.

\begin{tabular}{|c|c|c|c|c|c|c|}
\hline \multirow[t]{2}{*}{ Variables } & \multicolumn{4}{|c|}{$\begin{array}{c}\text { Inclusion levels residue from the extraction of tamarind pulp in } \\
\text { the experimental rations }(\%)\end{array}$} & \multirow[t]{2}{*}{ Regression } & \multirow[t]{2}{*}{$\% \mathrm{CV}$} \\
\hline & $0 \%$ & $5 \%$ & $10 \%$ & $15 \%$ & & \\
\hline NI g day ${ }^{-1}$ & 52.17 & 55.64 & 56.36 & 55.69 & $\mathrm{Y}=54.96$ & 6.93 \\
\hline NI $g_{k g}^{0,75-1}$ & 3.33 & 3.43 & 3.47 & 3.55 & $\mathrm{Y}=3.44$ & 8.00 \\
\hline FN g day ${ }^{-1}$ & 12.61 & 14.53 & 15.02 & 16.97 & $Y=14.78$ & 14.78 \\
\hline $\mathrm{FN} \mathrm{g} \mathrm{kg}{ }^{0,75-1}$ & 0.82 & 0.89 & 0.92 & 1.08 & $\mathrm{Y}=0.93$ & 15.66 \\
\hline $\mathrm{FN} \% \mathrm{CN}$ & 24.07 & 25.99 & 26.61 & 30.50 & 1 & 10.10 \\
\hline UN g day ${ }^{-1}$ & 11.51 & 11.04 & 12,46 & 1093 & $\mathrm{Y}=11.49$ & 21.37 \\
\hline $\mathrm{UN} \mathrm{g} \mathrm{kg}^{0,75-1}$ & 0.74 & 0.68 & 0.77 & 0.70 & $\mathrm{Y}=0.72$ & 23.65 \\
\hline $\mathrm{UN} \% \mathrm{CN}$ & 1.41 & 1.23 & 1.37 & 1.26 & $\mathrm{Y}=1.32$ & 22.62 \\
\hline NB $g$ day ${ }^{-1}$ & 28.04 & 30.07 & 28.88 & 27.79 & $\mathrm{Y}=28.70$ & 9.43 \\
\hline NB $g_{k g}^{0,75-1}$ & 1.77 & 1.86 & 1.78 & 1.77 & $\mathrm{Y}=1.79$ & 8.90 \\
\hline $\mathrm{NB} \% \mathrm{CN}$ & 54.08 & 54.13 & 51.24 & 49.86 & $\mathrm{Y}=52.33$ & 10.65 \\
\hline $\mathrm{NA}_{\mathrm{g}}$ day $^{-1}$ & 39.55 & 41.12 & 41.34 & 38.72 & $Y=40.18$ & 5.85 \\
\hline
\end{tabular}




\begin{tabular}{lcccccc}
\hline AN g kg \\
\hline $0,75-1$ & 2.51 & 2.54 & 2.55 & 2.47 & $\mathrm{Y}=2.52$ & ... Continuation \\
$\mathrm{AN} \mathrm{\%} \mathrm{CN}$ & 75.94 & 74.01 & 73.39 & 69.50 & 2 & 3.69 \\
$\mathrm{NB} \mathrm{NI}^{-1}$ & 0.54 & 0.54 & 0.51 & 0.50 & $\mathrm{Y}=0.52$ & 10.65 \\
$\mathrm{NB} \mathrm{AN}^{-1}$ & 0.71 & 0.73 & 0.70 & 0.72 & $\mathrm{Y}=0.71$ & 8.17 \\
\hline
\end{tabular}

${ }^{1} \mathrm{Y}=23.8034+0.398556 \mathrm{X}\left(\mathrm{r}^{2}=38.90 \%\right) ;{ }^{2} \mathrm{Y}=76.1966-0.398556 \mathrm{X}\left(\mathrm{r}^{2}=38.90 \%\right)$

$\mathrm{NI}$ : Nitrogen intake; $\mathrm{g}\left(\mathrm{kg}^{0,75}\right)^{-1}$ : grams per kilogram of metabolic weight; \% CN: percentage of consumed nitrogen; FN: fecal nitrogen; UN: urinary nitrogen; NB: nitrogen balance; AN: absorbed nitrogen. \% CV: coefficient of variation.

The value of FN expressed as a percentage of the $\mathrm{CN}$ showed increasing linear behavior $(p<0.05)$ with the addition of RETP in the diets, which corroborates the pharmaceutical industry's statement that tamarind has laxative activity (GURJÃO, 2006).

The evaluation of the metabolism of nitrogenous compounds in sheep fed diets containing $0.0 \%$, $33.0 \%, 67.0 \%$, and $100.0 \%$ detoxified mammon meal was conducted by Silva et al. (2010), who did not observe $(\mathrm{p}>0.05)$ changes in NI, which averaged $26.70 \mathrm{~g} \cdot$ day $^{-1}$ over the different treatment diets.

According to Van Soest (1994), losses of FN in ruminants can range between $6 \%$ and $8 \%$ of the $\mathrm{CP}$ intake. The average $\mathrm{CP}$ intake in diets containing different levels of RETP was 343.52 $\mathrm{g} \cdot$ day $^{-1}$ according to Geron et al. (2013b), and the average value of FN was $14.78 \mathrm{~g} \cdot$ day $^{-1}$ (Table 3), which gives an estimated loss of $4.30 \%$. The limited mobilization of $\mathrm{N}$ from muscle reduces urinary and fecal N excretion (VAN SOEST, 1994), which avoids waste and environmental contamination.

Varying levels of RETP did not affect ( $p>0.05)$ $\mathrm{UN}$, which had means of $11.49 \mathrm{~g} \cdot$ day $^{-1}, 0.72 \mathrm{~g} \cdot(\mathrm{kg}$ $\left.{ }^{0.75}\right)^{-1}$, and $\mathrm{CN}$ of $1.32 \%$. The EE values of the diets, which varied from $1.76 \%$ to $2.14 \%$, and increased proportionally to the level of RETP, did not affect the fermentation of DM and OM in the rumen, which influenced the UN values in this study. However, a study conducted by Ozino et al. (2013), which evaluated different sources of fiber in a forage-based cactus diet in sheep, demonstrated that Tifton 85 hay containing cottonseed showed higher UN excretion $(\mathrm{p}<0.05)$ compared to the diet without cottonseed. The authors suggest that diets with cottonseed containing $4.20 \%$ of EE may have reduced $\mathrm{N}$ availability due to the reduction of organic matter digestibility from the addition of fiber (OZINO et al., 2013).

Ruminal ammonia can be absorbed through the rumen wall in its non-ionized form $\left(\mathrm{NH}_{3}\right)$, but not its ionized form $\left(\mathrm{NH}_{4}^{+}\right)$(SANTOS; PEDROSO, 2011). Therefore, reductions in ruminal $\mathrm{pH}$ favor $\mathrm{NH}_{4}^{+}$, which reduces its absorption, while an increase in rumen fluid $\mathrm{pH}$ favors $\mathrm{NH}_{3}$, which increases ammonia absorption. As there was no effect ( $p>0.05$ ) of inclusion of RETP in the diet on the $\mathrm{pH}$ of the rumen fluid, these data corroborate the average value of $11.49 \mathrm{~g} \cdot$ day $^{-1}$ obtained for the excretion of UN.

The different levels of RETP did not affect ( $p>$ 0.05 ) the $\mathrm{NB}$, or retained $\mathrm{N}$, of sheep with average values of $28.70 \mathrm{~g} \cdot \mathrm{day}^{-1}, 1.79 \mathrm{~g} \cdot\left(\mathrm{kg}^{0.75}\right)^{-1}$, and $52.33 \%$ CN (Table 3). According to Ozino et al. (2013), sheep consuming diets containing 13\% CP and diverse fiber sources had a mean value of 13.35 $\mathrm{g} \cdot$ day $^{-1} \mathrm{NB}$, lower than that observed in this study. Specifically, we observed a value of $56.66 \%$ for the NB expressed as percentage $\mathrm{CN}$, a value similar to the observed mean $(52.33 \% \mathrm{CN})$ in diets containing different levels of RETP (Table 3).

For AN in $\mathrm{g} \cdot \mathrm{day}^{-1}$ and $\mathrm{g} \cdot\left(\mathrm{kg}^{0.75}\right)^{-1}$ (Table 3$)$, no effect ( $p>0.05$ ) was observed in sheep fed different levels of RETP. However, for AN in percentage $\mathrm{CN}$, a decreasing linear effect was observed $(p<0.05)$ with the addition of RETP to the diets, an effect 
probably explained by the increase $(\mathrm{p}<0.05)$ in $\mathrm{FN}$.

For the ratios of $\mathrm{NB} \cdot \mathrm{NI}^{-1}$ and $\mathrm{NB} \cdot \mathrm{NA}^{-1}$, no effect was observed $(p<0.05)$ with the inclusion of RETP (Table 3). Nitrogen retention, i.e., NB in relation to the $\mathrm{AN}$, reflects the utilization of $\mathrm{N}$ in tissue protein synthesis, the formation of new tissues or enzyme systems, or the replacement of old tissue or epithelia (EZEQUIEL et al., 2000). The efficiency of this activity depends on the composition of the $\mathrm{N}$ compound that reaches the tissue after intestinal absorption. The results obtained in this study indicate that the proteins or other $\mathrm{N}$ forms in RETP were used equivalently, regardless of the level of inclusion of RETP.

The inclusion of up to $15.0 \%$ RETP in sheep diets does not alter the $\mathrm{pH}, \mathrm{NH}_{3}-\mathrm{N}$ from rumen fluid, NI, UN, or NB. The inclusion of $15.0 \%$ RETP does, however, have a laxative affect.

\section{Acknowledgements}

The authors thank the Fundação de Amparo à Pesquisa do Estado de Mato Grosso - FAPEMAT for having funded this study (Protocol 332918/2012) and for awarding Scientific Initiation Scholarships to students in the Animal Science Course. We also thank The Universidade do Estado de Mato Grosso (UNEMAT) - Campus University de Pontes e Lacerda, for fostering this research by providing the facilities of the Animal Metabolism Sector and equipment from the Food and Animal Nutrition Analysis Laboratory.

\section{References}

EZEQUIEL, J. M. B.; SAMPAIO, A. A. M.; SEIXAS, J. R. C.; OLIVEIRA, M. M. Balanço de nitrogênio e digestão total da proteína e da energia de rações contendo farelo de algodão, levedura de cana-de-açúcar ou uréia em ovinos. Revista Brasileira de Zootecnia, Viçosa, MG, v. 29, n. 6, p. 2332-2337, 2000. Suplemento 2.

FENNER, H. Method for determining total volatile bases in rumen fluid by steam destilation. Journal of Dairy Science, Champaign, v. 48, n. 4, p. 249-251, 1965.
GERON, L. J. V.; MEXIA, A. A.; CRISTO, R. L.; GARCIA, J.; CABRAL, L. S.; TRAUTAMANN, R. J.; MARTINS, O. S.; ZEOULA; L. M. Consumo, digestibilidade dos nutrientes e características ruminais de cordeiros alimentados com níveis crescentes de concentrado em ambiente tropical no Vale do Alto Guaporé - MT. Semina: Ciências Agrárias, Londrina, v. 34, n. 5, p. 2497-2510, $2013 \mathrm{a}$.

GERON, L. J. V.; SILVA, M. I. L.; GARCIA, J.; COSTA, F. G.; CRISTO, R. L.; OLIVEIRA, E. B.; TONIOLO, J.; SOUZA, W. G. Consumo de nutrientes em cordeiros alimentados com rações contendo níveis crescentes de resíduo agroindustrial - Tamarindus indica. In: CONGRESSO BRASILEIRO DE ZOOTECNIA, 23., 2013, Foz do Iguaçu. Anais... Foz do Iguaçu: ZOOTEC, 2013b. CD-ROM.

GERON, L. J. V.; ZEOULA, L. M.; PAULA, E. J. H.; RUPPIN, R. F.; RODRIGUES, D. N.; MOURA, D. C. Inclusão do caroço de algodão em rações de alto concentrado constituído de co-produtos agroindustriais sobre o desempenho animal em tourinhos confinados. Archives of Veterinary Science, Curitiba, v. 16, n. 3, p. 14-24, 2011.

GERON, L. J. V.; COSTA, F. G.; SANTOS, R. H. E.; GARCIA， J.; TRAUTMANN-MACHADO, R. J.; SILVA, M. I. L.; ZEOULA, L. M.; SILVA, D. A. Balanço de nitrogênio em cordeiros alimentados com rações contendo diferentes teores de concentrado. Semina: Ciências Agrária, Londrina, v. 36, n. 3, p. 1609-1622, 2015.

GUIMARÃES JÚNIOR，R.; GONÇALVES，L. C.; PEREIRA, L. G. R., PIRES, D. A. A.; RODRIGUES, J. A. S.; MIRANDA, K. L.; ARAÚJO, V. L. Balanço de nitrogênio em ovinos alimentados com silagens de três genótipos de milheto [Pennisetum glaucum (L.) R. Br.]. In: REUNIÃO ANUAL DA SOCIEDADE BRASILEIRA DE ZOOTECNIA, 44., 2007, Jaboticabal. Anais... Jaboticabal: SBZ, 2007. CD-ROM.

GURJÃO, K. C. O. Desenvolvimento, armazenamento e secagem de tamarindo (Tamarindus indica L.). 2006. Tese (Doutorado em Agronomia) - Universidade Federal da Paraíba, Areias.

HENRIQUE, W.; SAMPAIO, A. A. M.; LEME, P. R.; ALLEONI, G. F.; LANNA, D. P. D.; MALHEIROS, E. B. Digestibilidade e balanço de nitrogênio em ovinos alimentados á base de dietas com elevado teor de concentrado e níveis crescentes de polpa cítrica peletizada. Revista Brasileira de Zootecnia, Viçosa, MG, v. 32, n. 6, p. 2007-2015, 2003. Suplemento 2.

HRISTOV, A.; BRODERICK, G. A. In vitro determination of ruminal protein degradability using $(15 \mathrm{~N})$ ammonia to 
correct for microbial nitrogen uptake. Journal of Animal Science, Champaign, v. 72, n. 5, p. 1344-1354, 1994.

MAEDA, E. M.; ZEOULA, L. M.; GERON, L. J. V.; BEST, J.; PRADO, I. N.; MARTINS, E. N.; KAZAMA, R. Digestibilidade e características ruminais de dietas com diferentes níveis de concentrado para bubalinos e bovinos. Revista Brasileira de Zootecnia, Viçosa, MG, v. 36, n. 3, p. 716-726, 2007.

MORENO, G. M. B.; SILVA SOBRINHO, A. G.; LEÃO, A. G.; LOUREIRO, C. M. B.; PEREZ, H. L.; ROSSI, R. C. Desempenho, digestibilidade e balanço de nitrogênio em cordeiros alimentados com silagem de milho ou canade-açúcar e dois níveis de concentrado. Revista Brasileira de Zootecnia, Viçosa, MG, v. 39, n. 4, p. 853-860, 2010.

NATIONAL RESEARCH COUNCIL - NRC. Nutrient requeriments of small ruminants: sheep, goats, cervids, and new world camelids. Washington D.C. USA: National Academy Press, 2007. 362 p.

OZINO, R. A.; FERREIRA, M. A.; VERAS, A. S. C.; COSTA, S. B. M.; CONCEIÇÃO, M. G.; SILVA, E. C.; SALLA, L. E.; SOUZA, A. R. D. L. Diferentes fontes de fibra em dietas a base de palma forrageira na alimentação de ovinos. Revista Brasileira de Saúde e Produção Animal, Salvador, v. 14, n. 4, p. 648-659, 2013.

PEREIRA, E. P.; MIZUBUTI, I. Y.; VILLARROEL, A. B. S.; OLIVEIRA, S. M. P.; PIMENTEL, P. G. Variáveis ruminais em novilhos alimentados com feno de tifton 85 com diferentes tamanhos de partículas. Semina: Ciências Agrárias, Londrina, v. 30, n. 1, p. 243-250, 2009.

PEREIRA, P. C.; MELO, B.; FRAZÃO, A. A.; ALVES, P. R. B. A cultura do tamarindo (Tamarindus indica L). Uberlândia: Universidade Federal de Uberlândia, 2004. Disponível em: <http://www.fruticultura.iciag.ufu.br/ tamarindo.htm>. Acesso em: 2 nov. 2013.

SANTOS, F. A. P.; PEDROSO, A. M. Metabolismo de proteínas. In: BERCHIELLI, T. T.; PIRES, A. V.; OLIVEIRA, S. G. Nutrição de ruminantes. 2. ed. Jaboticabal: Funep, 2011. p. 265-292.

SILVA, D. C.; ALVES, A. A.; VASCONCELOS, V. R.; NASCIMENTO, H. T. S.; MOREIRA FILHO, M. A.; OLIVEIRA, M. E. Metabolismo dos compostos nitrogenados em ovinos alimentados com dietas contendo farelo de mamona destoxificado. Acta Scientiarum. Animal Sciences, Maringá, v. 32, n. 2, p. 219-224, 2010.
SILVA, D. J.; QUEIROZ, A. C. Análise de alimentos: métodos químicos e biológicos. 2. ed. Viçosa, MG: UFV, 2002. $178 \mathrm{p}$.

SNIFFEN, C. J.; O'CONNOR, J. D.; VAN SOEST, P. $\mathrm{J}$. A net carbohydrate and protein system for evaluating cattle diets II. Carbohydrate and protein availability. Journal of Animal Science, Champaing, v. 70, n. 11, p. 3562-3577, 1992.

UNIVERSIDADE FEDERAL DE VIÇOSA - UFV. Sistemas de análises estatísticas e genéticas - SAEG. Versão 9.1. manual do usuário. Viçosa: Imprensa Universitária, 2007. 150 p.

VAN SOEST, P. J. Nutritional ecology of the ruminant. $2^{\text {th }}$ ed. London: Constock Publishing Associates, 1994. $476 \mathrm{p}$.

VAN SOEST, P. J.; ROBERTSON, J. B.; LEWIS, B. A. Methods for dietary fiber neutral detergent fiber, and nostarch polysaccharides in relation to animal nutrition. Journal of Dairy Science, Champaing, v. 74, n. 12, p. 3583-3597, 1991.

VIEIRA, P. F. Efeito do formaldeído na proteção de proteinas e lipídios em rações para ruminantes. 1980. Tese (Doutorado em Zootecnia) - Universidade Federal de Viçosa, Viçosa, MG.

ZEOULA, L. M.; CALDAS NETO, S. F.; GERON, L. J. V.; MAEDA, E. M.; PRADO, I. N.; DIAN, P. H. M. Substituição do milho pela farinha de varredura de mandioca (Manihot esculenta, Crantz) em rações de ovinos: consumo, digestibilidade, balanços de nitrogênio e energia e parâmetros ruminais. Revista Brasileira de Zootecnia, Viçosa, MG, v. 32, n. 2, p. 491-502, 2003.

ZEOULA, L. M.; FERELI, F.; PRADO, I. N.; GERON, L. J. V.; CALDAS NETO, S. F.; PRADO, O. P. P.; MAEDA, E. M. Digestibilidade e balanço de nitrogênio com diferentes teores de proteína degradável no rúmen e milho como fonte de amido em ovinos. Revista Brasileira de Zootecnia, Viçosa, MG, v. 35, n. 5, p. 2179-2186, 2006.

ZEOULA, L. M.; PRADO, O. P. P.; GERON, L. J. V.; BELEZE, J. R. F.; AGUIAR, S. C.; MAEDA, E. M. Digestibilidade total e degradabilidade ruminal in situ de dietas volumosas com inclusão de ionóforo ou probiótico para bubalinos e bovinos. Semina: Ciências Agrárias, Londrina, v. 35, n. 4, p. 2063-2076, 2014. 